CCIJ

26,5

Received 22 October 2020

Revised 20 January 2021 19 March 2021

Accepted 19 March 2021

\section{Assessing dialogic features of corporate pages on Facebook in Latin American companies}

\author{
Paul Capriotti \\ Department of Communication Studies, Rovira i Virgili University, Tarragona, Spain \\ Ileana Zeler \\ Department of Advertising, Public Relations and Audiovisual Communication, \\ Autonomous University of Barcelona, Bellaterra, Spain, and \\ Andrea Oliveira \\ Department of Philology and Communication, University of Girona, Girona, Spain
}

\begin{abstract}
Purpose - This study aims to analyze whether companies from six Latin American countries are encouraging dialogic communication on Facebook.

Design/methodology/approach - To do so, the paper studied the level of predisposition for interaction and the type of interaction achieved by companies on Facebook to produce an effective dialogic communication exchange and to generate conversation through different types of communication exchange between organizations and users. This research includes a specific analysis of the active presence, interactive attitude, interactive resources, responsiveness and conversation of 29,078 posts on 135 corporate fanpages of companies from six Latin American countries.

Findings - The results show that companies have a low interest in managing communication from a dialogic perspective on the social network, not only because a greater predisposition to interaction is needed, but also because the interaction generated is very low. Therefore, the paper identifies the need to review the communication strategy on social networks and to define a strategy aligned to the dialogic nature of the social network.

Originality/value - This research contributes to broadening the conceptual reflection on the evaluation of the dialogue in the digital context and aims to generate new methodological contributions to the evaluation of dialogic communication in an integrated way.
\end{abstract}

Keywords Corporate communication, Dialogic communication, Responsiveness, Conversation, Interaction, Dialogue, Social networks, Facebook

Paper type Research paper

\section{Introduction}

Social networks have turned into a relevant instrument of organizational communication since they allow a more participatory communicational model based on interaction and dialogue. Different authors (Kim et al., 2014; Waters et al., 2009; Wissen, 2017) maintain that the basis of communication management on social networks lies in the principles of dialogic communication. Through the dialogue and the creation of collaborative channels on social networks, companies can understand their stakeholders better, as well as gain awareness about their opinions and feelings, promote their activities and increase their visibility and reputation (Gonçalvez Pereira et al., 2014).

(C) Paul Capriotti, Ileana Zeler and Andrea Oliveira. Published by Emerald Publishing Limited. This article is published under the Creative Commons Attribution (CC BY 4.0) licence. Anyone may reproduce, distribute, translate and create derivative works of this article (for both commercial and noncommercial purposes), subject to full attribution to the original publication and authors. The full terms of this licence may be seen at http://creativecommons.org/licences/by/4.0/legalcode
Corporate Communications: An International Journal Vol. 26 No. 5,2021 pp. $16-30$ Emerald Publishing Limited 1356-3289 DOI 10.1108/CCIJ-10-2020-0149 
Chung et al. (2017) state there is no itinerary established to manage the communication of the organizational activities on social networks, but that these have a strong potential to revolutionize the way organizations interact with their stakeholders. Based on a study conducted by members of the Public Relations Society of America (PRSA), professionals now agree more than ever about the fact that social networks are changing the way organizations communicate with their stakeholders (Wright and Drifka Hinson, 2017).

Facebook is the social network with the greatest participation in the world as well as the most used. Its fanpages allow organizations to have a public identity of their own on Facebook (Cho et al., 2016), through which they can share content related to the organization and its activity. The maturity reached by Facebook, as well as the consolidation of digital consumption habits of stakeholders, led organizations to recognize the potential of the social network and to include it among the communication strategies (DiStaso and McCorkindale, 2013; Lee, 2016; Neill and Moody, 2015).

\section{Theoretical background}

According to Capriotti and Pardo Kuklinski (2012), dialogic communication is defined as "an ongoing interaction between organizations and their stakeholders using Internet tools, which enables information, comments, opinions, assessment, and experiences to be exchanged on a continuous basis" (p. 620). It is the framework for building and keeping relationships between organizations and their stakeholders on the Internet (Kent and Taylor, 2002). In social networks, the interaction can be initiated when organizations send information and/or consult users about their activities through the content published in their social profiles, or when users communicate their opinions and need to organizations (Anderson et al., 2016).

Even though the initiative can come from organizations as well as users, for the dialogic exchange to take place, organizations must show a willingness to interact and foster conversations with users on platforms. The conceptual approaches about dialogic communication (Kent and Taylor, 2002; Taylor and Kent, 2014) sustain that the dialogue involves, on the one hand, the will or predisposition of subjects (both organizations and users) to establish a communicational exchange and, on the other hand, the effective performance of interaction through different possible types of communicational exchange between an organization and its stakeholders.

\subsection{The predisposition toward interaction on Facebook}

Several authors (Botan, 1997; Kent and Taylor, 1998, 2002) maintain that the basis of dialogic communication lies in the predisposition toward interaction by subjects since if there is no will for interaction, it is very difficult that an effective dialogue might produce. A stable and continuous dialogue on social networks makes it possible to strengthen long-term relationships between organizations and their stakeholders, as long as an active presence is maintained to facilitate exchange, design content that promotes interaction and encourages conversations (Eberle et al., 2013). In this way, the first main research question (RQ) could be formulated as follows:

\section{$R Q 1$. What is the "predisposition toward interaction" of companies on Facebook?}

The predisposition toward interaction on social networks involves three key aspects: active presence (to keep a steady and stable activity that facilitates interaction), interactive attitude (to manifest the will or interest toward interaction) and interactive resources (to create and disseminate content encouraging interaction).

The active presence alludes to maintaining continuous visibility on social networks that allows, facilitates and promotes the communicational exchange between an organization and 
CCIJ

26,5

the users on social networks. Among the social networks available, Facebook has enormous potential for dialogic communication (Bortree and Seltzer, 2009). Facebook's capacity to favor interaction allows companies to have resources to broadcast videos live, disseminate stories live, the possibility to create events, the capacity to formulate questions, provide recommendations, launch surveys and so forth. Having an active presence on Facebook is key for the interaction with stakeholders, because the more active the presence is, the greater the possibility to generate conversation with users.

The interactive attitude refers to the way there is an encouragement to share, give an opinion, participate and collaborate in the communicational exchange between an organization and the users on social networks. For the communicational exchange to take place, organizations need to attract and motivate users to participate and share their opinions, and to do so, it is required to foster and encourage actions and content that promote conversation and collaboration (Safko and Brake, 2009). Developing a dialogic attitude on social networks demonstrates engagement, seriousness, responsibility and closeness from organizations, as well as a positive contribution to increasing trust among users.

The interactive resources refer to the way content is designed and elaborated to be shared in the communicational exchange between an organization and the users on social networks. To do so, organizations use in their content, different graphic, hypertextual and audiovisual elements that contribute to promoting interactions, such as text, images, emojis, links, hashtags, videos and GIFs (Zeler and Capriotti, 2018). According to Anderson et al. (2016), writing skills are resources that allow to draw the attention of users and to motivate them to comment and reply. The professionals of digital communication recognize the need of being concise and straightforward in the messages, use creativity and include keywords in their content to promote that users interact with them (Abitbol and Lee, 2017; Limongi França Coelho et al., 2016).

Based on these three aspects (active presence, interactive attitude and interactive resources), the general approach of the predisposition toward interaction on Facebook by organizations could be established. A higher level of activity, attitude and use of interactive resources will entail a higher predisposition toward interaction.

\subsection{Types of effective interaction on Facebook}

The fact of having an active presence, availability of interactive elements on content or having an interactive attitude on social networks does not lead directly to the effective interaction between organizations and users. Many studies conclude that, even though organizations have different interactive resources on social networks, these entities are not making the most of the said resources to encourage conversation, but instead massively disseminate their content in a unidirectional manner (Huang et al., 2016; Pang et al., 2018; Shin et al., 2015; Sundstrom and Levenshus, 2017; Wissen, 2017). The predisposition toward interaction is a basic "pre-condition" for the effective dialogue on social networks, but it does not ensure having a steady and continuous interaction between the organization and users. So, a second main research question $(\mathrm{RQ})$ is formulated:

RQ2. What sort of "effective interaction" are companies doing on Facebook?

The sort of communicational exchange between an organization and the users on social networks can be defined based on the level of continuity of the exchange between the involved parties. Some scholars have used the concept of social responsiveness to analyze the level of exchange and interaction among organizations and their publics in a bid to establish good social performance (Carroll, 1979; Wood, 1991; Pierick et al., 2004). Based on previous studies (Anderson et al., 2016; Kiousis, 2002; Rafaeli, 1988; Walther et al., 2010), two main types of interaction on social networks can be defined: responsiveness and conversation. 
Responsiveness involves a single interrelated communicational exchange (message delivery and reaction), and it is considered a response associated with the original message delivered, which represents a minimum basic level of exchange. This could be related to a low level of social responsiveness (Carroll, 1979; Wood, 1991; Pierick et al., 2004). Conversation leads to at least three interrelated communicational exchanges (message delivery, reply, new message delivery and so on), and it represents more accurately the idea of interaction and dialogic communication (Anderson et al., 2016; Kiousis, 2002; Rafaeli, 1988; Walther et al., 2010). This could be associated with a high level of social responsiveness (Carroll, 1979; Wood, 1991; Pierick et al., 2004).

In social networks, particularly on Facebook, two main resources allow users to generate responsiveness: Like and Share (Anderson et al., 2016; Macnamara, 2014). Like and Share are elements available for users to manifest that they agree or like the content. Like is a passive way to express appreciation for content without verbal expression, and Share allows users to be volunteer spokespersons of organizational messages toward their social groups (Abitbol and Lee, 2017; Cho et al., 2014).

However, these elements do not generate interaction on their own. The conversation on Facebook mainly manifests through Comment. It is the most genuine expression of interaction on social networks and the most relevant element to promote conversation on Facebook. It requires much more engagement than Like and Share, allows users to establish direct conversations with organizations and therefore facilitates the information exchange process in a steady and balanced manner between the organization and the users (Abitbol and Lee, 2017; Cho et al., 2014).

Based on both types of interaction (responsiveness and conversation), the level of communicational exchange between an organization and users on Facebook could be established, depending on the prominence of the different types of exchange. Greater implantation of the conversational exchange will entail a higher level of interaction.

\section{Purpose}

The regional growth and the integration of Latin America into the world economy have encouraged companies to have a greater need for increasing the levels of reliability and transparency toward their stakeholders. To achieve this, it is required that organizations build effective relationships with stakeholders through the management of dialogic communication. Communication on Facebook has a relevant role in Latin American companies. Facebook is the most popular social network in Latin America (Castro and Vega, 2018), and it can be a key tool to promote the dialogue between companies and digital users.

The general objective of this article is to study whether companies from six Latin American countries are encouraging dialogic communication on Facebook. To comply with this goal, two specific objectives were established: (1) to analyze the predisposition of companies toward interaction on Facebook and (2) to assess the type of interaction achieved by companies on Facebook.

\section{Methodology}

This study is focused on the analysis of dialogic communication on Facebook by companies in Latin America which are considered a reference on communication management issues. Likewise, they are the ones allocating relevant resources to innovate and to be at the forefront of digital communication.

To identify the companies in Latin America, countries with the highest GDP in the Statistical Yearbook of Latin America and the Caribbean of ECLAC (Economic Commission of Latin America and The Caribbean) were selected, and in which the most important annual 
CCIJ

26,5

20

study of corporate reputation elaborated by Monitor Empresarial de Reputación Corporativa (MERCO) [Business Monitor of Corporate Reputation] has been carried out for over 2 years (2013 and 2014). Thus, 157 companies from six Latin American countries were selected: Brazil, Argentina, Chile, Peru, Colombia and Mexico.

From the total companies identified (157), those having corporate official fanpages countrywide were selected. The social profiles were identified through the official websites of the companies and the popular search engines on the Internet. The profiles that could not be verified were discarded. Thus, the final sample included 135 Facebook profiles: 25 from Brazil, 19 from Chile, 19 from Mexico, 23 from Argentina, 27 from Colombia and 22 from Peru.

For posts collection, a study of two years (2015 and 2016) was done to identify similarities and differences in communication management on the social network. Given the high volume of posts identified (more than 120,000), a selection was made following two periods: from January until June 2015 and from July to December 2016. In both periods, 2 weeks per month were considered: odd weeks in 2015 and even weeks in 2016. Finally, the sample included 29,078 posts.

To answer the two main research questions (RQs) defined in the theoretical background, the content analysis methodology was used, and five categories of analyses were defined: active presence, interactive attitude, interactive resources, responsiveness and conversation. These categories were developed and tested in prior studies (Capriotti et al., 2016; Zeler and Capriotti, 2017) (Figure 1).

For RQ1 (predisposition toward interaction), three categories of analysis were established: active presence, interactive attitude and interactive resources.

The category of "active presence" analyzes the active and steady use of Facebook that allows, facilitates and encourages sharing information and the interaction between an organization and users. To do so, two dimensions were established: (1) level of presence: to determine whether companies have official corporate fanpages on Facebook; (2) level of activity: to analyze the weekly and daily average of posts by companies in the social network. A greater active presence will involve a higher predisposition toward interaction.

The category of "interactive attitude" analyzes the general communication approach of companies based on the identification of different aspects that establish the way content is designed and presented, that allow interaction to a higher or lower extent. To do so, the type of presentation of content was defined in terms of the communicational exchange between an organization and its stakeholders based on two aspects: (1) informational approach, referring to the creation and presentation of content with a merely informative, descriptive and expository perspective, encouraging a unidirectional communication; (2) interactive approach, referring to the creation and dissemination of content that promotes the exchange of information and conversation, facilitating the bidirectional communication even

Figure 1.

"Categories of Dialogic Communication Analysis"

\begin{tabular}{|c|c|c|c|}
\hline Presence & Active Precence & \multirow{7}{*}{$\begin{array}{l}\text { Predisposition } \\
\text { to Interaction }\end{array}$} & \multirow{11}{*}{$\begin{array}{l}\text { Dialogic } \\
\text { Communication }\end{array}$} \\
\hline Activity & Active riesente & & \\
\hline Informational & \multirow{2}{*}{ Interactive Attitude } & & \\
\hline Interactive & & & \\
\hline Graphic Resources & \multirow{3}{*}{ Interactive Resources } & & \\
\hline AV Resources & & & \\
\hline Hypertextual Resources & & & \\
\hline Support & \multirow{2}{*}{ Responsiveness } & \multirow{4}{*}{$\begin{array}{l}\text { Effective } \\
\text { Interaction }\end{array}$} & \\
\hline Viralization & & & \\
\hline Intensity & \multirow{2}{*}{ Conversation } & & \\
\hline Reciprocity & & & \\
\hline
\end{tabular}


more (encourages to participate, share, subscribe to an activity, provide an opinion, answer questions, etc.). Greater implantation of the interactive approach will involve a higher predisposition toward interaction.

The category of "interactive resources" examines the tools available on content that allow promoting the interaction and dialogue with the users on social networks. Facebook enables the exchange of information through different formats that can be combined between them. Thus, three main types of resources were defined: (1) graphic resources: composed of fixed images, texts and emojis; these are resources that promote the dissemination of information in a mainly monological manner; (2) audiovisual resources: composed of audios, videos and animated images (GIFs); these are recourses that generate a greater reach and involve a greater engagement since they have a higher capacity to appeal to emotions and require a longer period to dedicate attention from users; and (3) hypertextual resources: composed of links, hashtags and tag to users; these are resources that proactively foster exchange of information and widely allude to participation, interaction and engagement. Greater availability and use of hypertextual and audiovisual resources will entail a higher predisposition toward interaction.

To respond to RQ2 (the type of effective interaction), two categories of analyses were established: responsiveness and conversation.

The category "Responsiveness" allows analyzing the number of replies provided in each one of the posts published by companies. To study the level of responsiveness, two dimensions were established: (1) support: it is the Like rate, obtained using the total average of likes by company and posts concerning the number of followers of the company, multiplied by 100; (2) viralization: it is the Share rate, obtained from the total average of shares by company and posts concerning the number of followers of the company, multiplied by 100 . With this, the level of responsiveness in the communicational exchange between an organization and users on Facebook can be established.

The category "Conversation" allows assessing the communicational exchange generated between an organization and the users based on posts and comments on Facebook. To assess the conversation, two dimensions were defined: (1) intensity, which refers to the total general number of exchanges between an organization and its stakeholders, based on the rate of comments obtained from the division of the total number of comments of both companies and users per post concerning the total followers, multiplied by 100; and (2) reciprocity, which refers to the level of balance in the exchange between an organization and its stakeholders, obtained from the total percentage of comments made by users and companies. It is relevant to consider the number of messages delivered in one direction (from an organization toward the public) compared to the number of messages delivered the other way around (from the public toward an organization). Thus, the more balanced the communicational exchange between an organization and its stakeholders (with percentages close to 50/50\%), the greater the quality of the interaction. And the more imbalanced the communicational exchange between an organization and its stakeholders (with percentages between 10/90\% and $0 / 100 \%$ ), the poorer the quality of the interaction.

For this study, a content analysis of the 29,078 posts selected through an Excel template was performed manually by two of the project researchers during 2015 and 2016. The collection of posts was performed using a monitoring tool available on the Internet called Fanpage Karma. The information obtained was entered and coded into the Excel template designed especially for this study.

\section{Results}

Research indicates there were no substantial differences in the periods studied (2015-2016). Thus, the results are presented globally and organized based on the research questions (RQs) Formulated.

\section{Assessing dialogic features on Facebook}


$\mathrm{CCIJ}$

26,5

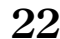

\subsection{The predisposition of companies toward interaction on Facebook}

The first research question (RQ1) analyzes the predisposition of companies toward interaction on Facebook based on active presence, interactive attitude and interactive resources.

The analysis of the "active presence" of companies on Facebook revealed that companies have a quite active presence on Facebook (Table 1). Most companies have a presence, and their activity is rather frequent on the social network. More than $80 \%$ of companies have fanpages in the social network studied and publish an average of 8.4 posts per week, mainly more than 1 post per day. The results by country follow the general trend, with no significant differences among countries (Table 1).

In terms of "interactive attitude" on Facebook, the Latin American companies studied present content with a merely informational and unidirectional approach (Table 2). Almost three-fourths of posts correspond to messages of informational nature $(74 \%)$, a prominent majority versus posts having a more interactive approach (26\%). This means that the exchange of information and the conversation through shared content is promoted on a few occasions. The analysis of the six Latin American countries shows similar results, having low significant differences versus the aforementioned (Table 2).

In terms of the "interactive resources," the results indicated that companies mainly use graphic resources to create and present content on Facebook (Table 3). Almost all the posts have a text $(97.8 \%)$, and fixed images are selected mostly to accompany them $(77.3 \%)$. In a few cases, emoticons are included (less than 10\%). Hypertextual resources are also used by companies. Approximately less than half of the posts have one or more links $(48.6 \%)$ and hashtags $(40.6 \%)$. The tags to other users are used least $(15.8 \%)$, and other resources are considered valuable to encourage interaction on Facebook (audio-video and GIFs). Audiovisual resources are scarcely used by companies for introducing content, with about $10 \%$ of posts include videos $(12.7 \%)$ or GIFs $(9.8 \%)$. Comparing the six different countries analyzed, it is observed that all of them mainly use texts and images to introduce content, but it is worth mentioning some little differences in the use of some audiovisual and hypertextual content among countries (Table 3).

Table 1.

The active presence of companies on

Facebook

\begin{tabular}{lccrrrrr}
\hline & Latin America & Argentina & Brazil & Chile & Colombia & Mexico & Peru \\
\hline Presence & & & & & & & \\
Yes & 86.5 & 88.5 & 92.6 & 82.6 & 90.0 & 82.6 & 78.6 \\
No & 13.5 & 11.5 & 7.4 & 17.4 & 10.0 & 17.4 & 21.4 \\
Activity & & & & & & & \\
Weekly average & 8.4 & 7.7 & 7.0 & 12.6 & 9.1 & 9.1 & 7.0 \\
Daily average & 1.2 & 1.1 & 1.0 & 1.8 & 1.3 & 1.3 & 1.0 \\
\hline
\end{tabular}

Communication approach of companies on Facebook (\%)

Informational approach

Interactive approach

Latin America
Argentina
Brazil

\section{0}

71.5

75.0

71.6

Chile

76.5

78.0

Peru
26.0

28.5

25.0

28.4

23.5

22.1

28.6 


\subsection{Type of effective interaction of companies on Facebook}

The second research question (RQ2) analyzes the communicational exchange generated between an organization and the users based on the level of responsiveness and conversation.

In terms of "Responsiveness," the volume of responses generated in each post published by the companies concerning the number of followers was assessed. The content of the Latin American companies studied generates a higher volume of likes compared to shares on Facebook (Table 4). The percentage of likes obtained is 11 times higher than shares. The viralization rate is $0.5 \%$ and the support rate is $5.7 \%$. This means that the level of responsiveness in the communicational exchange between companies and users on Facebook is rather low. Even though the percentage of support is much higher than viralization across the six Latin American countries, some significant differences were identified (Table 4). In Brazil, data show that the level of responsiveness is very low. Argentina and Colombia are the countries with higher rates of likes, but there is a difference in the results of the shares rate. Mexico, Chile and Peru receive lower rates of likes and shares than Argentina and Colombia, but they score much better than Brazil.

The "Conversation" was also analyzed. The intensity was determined in terms of communicational exchange generated between the companies and the users based on the total rate of comments in the organization's posts on Facebook. Even though the total rate of comments indicates that the communicational exchange is rather low (Table 5), users write more comments than companies $(0.3 \%)$. According to findings, companies practically do not reply to users' comments $(0.0 \%)$. This means that the communicational exchange between companies and users is almost nonexistent. Similar results are found in every Latin American country. In general, the total rate of comments obtained is very low. Practically, it is the users who generate a greater number of comments in companies' posts (Table 5). A comparative analysis between the six countries shows one significant result. Chile is the country with the

\begin{tabular}{|c|c|c|c|c|c|c|c|c|c|}
\hline & \multicolumn{3}{|c|}{ Graphic resources } & \multicolumn{2}{|c|}{$\begin{array}{l}\text { Audiovisual } \\
\text { resources }\end{array}$} & \multicolumn{3}{|c|}{ Hypertextual resources } & \\
\hline & Text & Image & Emoji & GIFs & Audio-video & US Tag & Hashtag & Link & \\
\hline Latin America & 97.8 & 77.3 & 12.1 & 8.6 & 12.7 & 15.8 & 40.6 & 48.6 & \\
\hline Argentina & 96.8 & 82.3 & 14.3 & 7.5 & 12.3 & 22.1 & 46.0 & 51.7 & \\
\hline Brazil & 97.3 & 73.9 & 20.1 & 5.6 & 15.1 & 15.1 & 33.5 & 64.3 & \\
\hline Chile & 98.3 & 77.1 & 17.4 & 13.0 & 9.0 & 7.3 & 38.6 & 53.6 & Table 3. \\
\hline Colombia & 97.5 & 76.3 & 5.7 & 7.0 & 11.8 & 14.0 & 43.7 & 39.0 & Interactive resources \\
\hline Mexico & 97.9 & 75.8 & 3.9 & 4.6 & 16.8 & 17.9 & 40.9 & 38.9 & used by companies on \\
\hline Peru & 98.8 & 79.1 & 11.1 & 14.1 & 13.2 & 23.0 & 40.2 & 45.5 & Facebook $(\%)$ \\
\hline
\end{tabular}

\begin{tabular}{|c|c|c|c|c|c|}
\hline & $\begin{array}{c}\text { Followers } \\
\text { Average/country }\end{array}$ & Support & $\begin{array}{l}\text { Rate } \\
\text { \% Total }\end{array}$ & Viralization & \\
\hline Latin America & $2,570,857$ & 5.7 & & 0.5 & \\
\hline Argentina & 989,182 & 14.8 & & 1.0 & \\
\hline Brazil & $10,574,786$ & 3.2 & & 0.2 & \\
\hline Chile & 517,086 & 11.6 & & 0.8 & Table 4. \\
\hline Colombia & 349,939 & 14.5 & & 2.2 & Responsiveness of \\
\hline Mexico & $1,535,478$ & 13.2 & & 1.5 & companies on \\
\hline Peru & 894,995 & 12.5 & & 0.8 & Facebook \\
\hline
\end{tabular}

Assessing dialogic features on Facebook

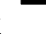


CCIJ 26,5

\section{4}

highest total rate of comments $(2.3 \%)$, basically because users of Chile write more comments with higher intensity than the rest of the countries in Latin America, but in general, companies do not participate.

Reciprocity was estimated based on the percentage of comments made by companies and users, which allowed us to obtain the level of communicational balance in terms of the interaction between companies and users on Facebook. Findings suggest the existence of a noteworthy communicational imbalance in the interaction between companies and users (Table 6). The comments of companies represent $11.8 \%$, and the users, $88.2 \%$. This represents a very low balance (between 10/90\% and 20/80\%). Analyzing the different Latin American countries, some significant differences were detected (Table 6). Even though the existence of a communicational imbalance is identified in the results of every of the six countries studied in Latin America, Mexico (19.4-80.6\%) and Peru (22.4-77.6\%) are the countries obtaining the best results, while Chile is the country obtaining the highest communicational imbalance $(4.3 / 95.7 \%)$.

\section{Discussion and conclusions}

The purpose of this study was to analyze whether companies from six Latin American countries are encouraging dialogic communication on Facebook. To do so, in the first place the level of predisposition toward interaction was analyzed, and then the type of interaction achieved by companies on Facebook was assessed. The findings of this research showed some interesting results.

The first aspect studied was "the predisposition towards interaction" by companies (RQ1). It revealed that companies have a low predisposition to interact with the users on Facebook because even though the results about "active presence" are good, the results about "interactive attitude" and "interactive resources" showed a discouraging scenario.

The intensity of the conversation on Facebook (\%)

\begin{tabular}{lccc}
\hline & Total & $\begin{array}{c}\text { Rate of comments } \\
\text { Companies }\end{array}$ & Users \\
\hline Latin America & 0.3 & 0.0 & 0.3 \\
Argentina & 0.8 & 0.1 & 0.7 \\
Brazil & 0.1 & 0.0 & 0.1 \\
Chile & 2.3 & 0.1 & 2.2 \\
Colombia & 0.6 & 0.1 & 0.5 \\
Mexico & 0.4 & 0.1 & 0.3 \\
Peru & 0.8 & 0.2 & 0.6 \\
\hline
\end{tabular}

Table 6.

Reciprocity of conversation on Facebook (\%)

\begin{tabular}{|c|c|c|}
\hline & \multicolumn{2}{|c|}{ Comments } \\
\hline & & \\
\hline Latin America & 11.8 & 88.2 \\
\hline Argentina & 8.9 & 91.1 \\
\hline Brazil & 9.2 & 90.8 \\
\hline Chile & 4.3 & 95.7 \\
\hline Colombia & 14.7 & 85.3 \\
\hline Mexico & 19.4 & 80.6 \\
\hline Peru & 22.4 & 77.6 \\
\hline
\end{tabular}


The results of "active presence" showed that companies analyzed in Latin America are mostly present and are quite active on Facebook. Unlike other studies conducted with different organizations of different countries and sectors (Altamirano Benitez et al., 2018; Devaney, 2015; Estudio de Comunicación, 2017; Kim et al., 2014; Quintly, 2016; Statista, 2017), companies analyzed have a quite active presence on Facebook. The active presence on this platform is key for interaction, but it does not produce interaction on its own. To promote interaction, it is necessary to share content that encourages it. Thus, the most interactive content is shared, the higher the likelihood to generate conversations with users.

In terms of the "interactive attitude," it was found that the general communication approach of companies is more unidirectional and informational rather than bidirectional and interactive. Having a dialogic attitude contributes positively to increase trust among users. However, the attitude of companies on Facebook is hardly dialogical. The results reveal that they do not encourage the communicational exchange with users through the creation of content that fosters participation, opinion, sharing and collaboration. Even though there are studies that indicate users are more willing to interact on content that promotes dialogue and conversation (Cho et al., 2014), the communicational attitude of companies analyzed on Facebook is mainly unidirectional (Aced-Toledano and Lalueza, 2018; Capriotti and LosadaDíaz, 2018; Huang et al., 2016; RivalIQ, 2018; Sundstrom and Levenshus, 2017; Wissen, 2017). If the content that users find in the Latin American companies' profiles is predominantly informative, the profiles could be considered not as a space for interaction, but solely as a source of information. This notably reduces the potential of this social network as a space for conversation (Abitbol and Lee, 2017; Cho et al., 2014) which promotes relationship building.

In terms of "interactive resources," the results revealed that companies mainly use resources with fewer possibilities to generate interaction. Posts usually use graphic resources (such as fixed images and texts), widely wasting audiovisual and hypertextual resources, which would allow reaching a higher level of interaction (Pletikosa Cvijikj and Michahelles, 2013). These results position in the same line as those of previous studies (Capriotti and Losada-Díaz, 2018; Luarn et al., 2015), but texts and images solely do not promote interaction. For this to happen, it is required that texts include questions, invitations to participate, share, subscribe to an activity or request opinions and/ or suggestions. Together with the findings of the "interactive attitude," it is evident that companies are essentially using the informational approach to create and disseminate texts and images.

The second aspect studied was "the type of effective interaction" generated about posts of companies (RQ2). The analysis indicated that practically there is no stable and steady interaction between companies and users on Facebook. On the contrary, the level of responsiveness is higher than the level of conversation. This suggests there is a minimum basic level of communicational exchange, determined by a single response generated by users about every post shared by companies, instead of multiple messages delivered and replies that represent conversation (Anderson et al., 2016; Kiousis, 2002; Rafaeli, 1988; Walther et al., 2010). Consequently, a low level of social responsiveness of organizations in Facebook is observed (Pierick et al., 2004).

The results about the "Responsiveness" showed a low level of it. Considering the high volume of followers of the Latin American companies studied (2.5 million), the rate of support and viralization obtained was rather low (support: $5.7 \%$; viralization: $0.5 \%$ ), even though there are significant differences detected between the different six Latin American countries. Considering that clicking likes is the passive way users show the appeal or agreement toward content, the study suggests that users mainly react passively toward companies' content. The fact that users prefer to click likes, instead of shares (resources that allow users to be volunteer spokespersons of content published by companies), can be because companies are generating the content of low interest, or because the content does not encourage interaction. In any case, if companies want to take advantage of Facebook's potential to increase their

\section{Assessing dialogic \\ features on \\ Facebook}


CCIJ

26,5

volume of viralization, they need to rethink their strategy for creating the content they broadcast through this network.

Similar results were observed in the "Conversation." The rate of comments identified was quite low $(0.3 \%$ total), even lower than likes and shares, with some noteworthy differences across the six countries in Latin America. Considering that comments are the most genuine expression of interaction on social networks, results showed that practically no conversation is generated. The study also demonstrates that companies scarcely interact in conversation or do not do so at all with users on Facebook. According to results on reciprocity, comments are generated mostly by users (almost $90 \%$ are users' comments and only 10\% are companies' comments). This indicates there is a noteworthy communicational imbalance between companies and users.

Thus, even though social networks have turned into key tools for the interactive and dialogic communication of companies toward users, the Latin American companies studied are broadly wasting the advantages of communication on Facebook. This study suggests that companies have a low interest to manage communication from a dialogical perspective in the social network, not only because a higher predisposition toward interaction is required but also because the interaction generated is rather low. The existence of a highly active presence of companies on Facebook, the fact that they mainly use resources that do not promote user interaction and participation and their low intensity of conversation with their followers could suggest that companies are using Facebook predominantly as their corporate showcase.

Communication management is merely unidirectional and monological. This trend has also manifested in other previous studies (Aced-Toledano and Lalueza, 2018; Capriotti and Losada-Díaz, 2018; Huang et al., 2016; RivalIQ, 2018; Sundstrom and Levenshus, 2017; Wissen, 2017), demonstrating the lack of a communicational strategy that adapts to the dialogic nature of Facebook. The tendency of companies to maintain a digital monologue on Facebook could be dangerous in this specific context, where the data show that users have a greater predisposition toward reciprocity of conversation than companies do. Such a situation could represent a risk for the dialogical communication of companies on the social network. If users lose interest in reciprocity of conversation, or worse, speculate that companies want their presence on their profile only for algorithmic studies, users could unfollow companies. This could imply a real impossibility of dialogue or the creation of relationships between organizations and their publics on this social network. Therefore, it is necessary to review the communication strategy on social networks and define a strategy aligned with the dialogic nature of the social network.

\section{Limitations and direction for future research}

The Internet has had an impact on many aspects of organizational structures and processes, and it has also affected how organizations and their stakeholders communicate with one another. The fluid and sustained dialogue over time has become the essential element of communication in social networks, promoting the building of relationships between organizations and their stakeholders in the digital ecosystem. For this, the organizational and professional barriers that are stopping the dialogic approach of digital communication need to be eliminated, since digital communication will continue to dominate how public relations are practiced (Sommerfeldt and Yang, 2018). In the current organizational context, more and more organizations are managing dialogic communication on social networks, but there is still a large percentage that does not. Among the main reasons that justify its operation are the limitation or lack of resources to implement dialogic communication (Sommerfeldt et al., 2012) and the lack of professional skills related to the analysis of trends and interactivity (Kent and Saffer, 2014). 
This research contributes to broadening the conceptual reflection on the evaluation of the dialogue in the digital context and aims to generate new methodological contributions to the evaluation of dialogic communication. This was obtained through the development of five key criteria or dimensions to operationalize such evaluation in social networks: active presence, interactive attitude, interactive information, responsiveness and conversation.

Even though this study is limited to the analysis of corporate communication in a specific social network (Facebook), for future studies, it would be convenient to analyze the situation in other popular social networks as well, such as Instagram, YouTube and Twitter. This way, it could be determined whether we are facing a problem of dialogic communication management on Facebook, or whether we are facing a general problem on social networks instead. Likewise, another relevant limitation is that this study was applied to companies. Considering that communication management on social networks is performed by all sorts of organizations, it would be interesting to apply the analysis to other non-governmental organizations and institutions in the future. Thus, it could be analyzed whether the results found in this study represent a particular situation of the use of social networks by companies from six Latin American countries, or if it is part of a current organizational trend.

\section{References}

Abitbol, A. and Lee, S.Y. (2017), "Messages on CSR-dedicated Facebook pages: what works and what doesn't”, Public Relations Review, Vol. 43 No. 4, pp. 796-808, doi: 10.1016/j.pubrev.2017.05.002.

Aced-Toledano, C. and Lalueza, F. (2018), "Monologues in the conversational era: assessing the level of dialogic communication that big firms are reaching on social media", El Profesional de lLa Información, Vol. 27 No. 6, p. 1270, doi: 10.3145/epi.2018.nov.10.

Altamirano Benitez, V., Marín-Gutiérrez, I. and Ordóñez González, K. (2018), "Comunicación turística 2.0 en Ecuador. Análisis de las empresas públicas y privadas”, Revista Latina de Comunicación Social, Vol. 73, pp. 633-647, doi: 10.4185/RLCS-2018-1273.

Anderson, B.D., Swenson, R. and Gilkerson, N.D. (2016), "Understanding dialogue and engagement through communication experts' use of interactive writing to build relationships", International Journal of Communication, Vol. 10, p. 24, available at: http://ijoc.org/index.php/ijoc/article/view/ 4569/1759.

Bortree, D.S. and Seltzer, T. (2009), "Dialogic strategies and outcomes: an analysis of environmental advocacy groups' Facebook profiles", Special Section on China Public Relations, Vol. 35 No. 3, pp. 317-319, doi: 10.1016/j.pubrev.2009.05.002.

Botan, C. (1997), "Ethics in strategic communication campaigns: the case for a new approach to public relations", Journal of Business Communication, Vol. 34 No. 2, pp. 188-202, doi: 10.1177/ 002194369703400205.

Capriotti, P. and Losada-Díaz, J.C. (2018), "Facebook as a dialogic communication tool at the most visited museums of the world", El profesional de la información, Vol. 27 No. 3, pp. 642-650, doi: 10.3145/epi.2018.may.17.

Capriotti, P. and Pardo Kuklinski, H. (2012), "Assessing dialogic communication through the Internet in Spanish museums”, Public Relations Review, Vol. 38 No. 4, pp. 619-626, doi: 10.1016/j.pubrev. 2012.05.005.

Capriotti, P., Carretón, C. and Castillo, A. (2016), "Testing the level of interactivity of institutional websites: from museums 1.0 to museums 2.0", International Journal of Information Management, Vol. 36 No. 1, pp. 97-104, doi: 10.1016/j.ijinfomgt.2015.10.003.

Carroll, A.B. (1979), “A three-dimensional conceptual model of corporate performance”, Academy of Management Review, Vol. 4 No. 4, pp. 497-505.

Castro, A. and Vega, F. (2018), El Estado de Social Media en América Latina, COMSCORE, available at: https://www.comscore.com/.

\section{Assessing dialogic features on Facebook}


CCIJ 26,5

Cho, M., Schweickart, T. and Haase, A. (2014), "Public engagement with nonprofit organizations on Facebook”, Public Relations Review, Vol. 40 No. 3, pp. 565-567, doi: 10.1016/j.pubrev.2014.01.008.

Cho, M., Furey, L. and Mohr, T. (2016), "Communicating corporate social responsibility on social media: strategies, stakeholders, and public engagement on corporate Facebook", Business and Professional Communication Quarterly, Vol. 80 No. 1, pp. 52-69, doi: 10.1177/2329490616663708.

Chung, A.Q.H., Andreev, P., Benyoucef, M., Duane, A. and O'Reilly, P. (2017), "Managing an organisation's social media presence: an empirical stages of growth model", International Journal of Information Management, Vol. 37 No. 1, pp. 1405-1417, doi: 10.1016/j.jinfomgt.2016. 10.003

Devaney, E. (2015), "Social media benchmarks rReport • 2015", available at: https://cdn2.hubspot.net/ hub/53/file-2415418647-pdf/00-OFFERS-HIDDEN/social-media-benchmarks-2015.pdf? $\mathrm{t}=1423113374840$.

DiStaso, M.W. and McCorkindale, T. (2013), "A benchmark analysis of the strategic use of social media for fortune's most admired U.S. Companies on Facebook, Twitter and Youtube”, Public Relations Journal, Vol. 7 No. 1, pp. 1-33.

Eberle, D., Berens, G. and Li, T. (2013), "The impact of interactive corporate social responsibility communication on corporate reputation", Journal of Business Ethics, Vol. 118 No. 4, pp. 731-746, doi: 10.1007/s10551-013-1957-y.

Estudio de Comunicación (2017), Presencia de las empresas del Ibex 35 en el entorno digital, Tercera edición, available at: http://www.estudiodecomunicacion.com/extranet/portfolio-view/presenciade-las-empresas-del-ibex35-en-el-entorno-digital/ (accessed 21 February 2017).

Gonçalvez Pereira, H., Salgueiro, M.de F. and Mateus, I. (2014), "Say yes to Facebook and get your customers involved! Relationships in a world of social networks", Business Horizons, Vol. 57, pp. 695-702, doi: 10.1016/j.bushor.2014.07.001.

Huang, Y.-C., Lin, Y. and Saxton, G.D. (2016), "Give me a like: how HIV/AIDS nonprofit organizations can engage their audience on Facebook", AIDS Education and Prevention, Vol. 28 No. 6, pp. 539-556, doi: 10.1007/s10551-015-2769-z.For.

Kent, M.L. and Saffer, A.J. (2014), "A Delphi study of the future of new technology research in public relations”, Public Relations Review. Elsevier, Vol. 40 No. 3, pp. 568-576, doi: 10.1016/j.pubrev. 2014.02.008.

Kent, M.L. and Taylor, M. (1998), "Building dialogic relationships through the world wide web", Public Relations Review, Vol. 24 No. 3, pp. 321-334, doi: 10.1016/S0363-8111(99)80143-X.

Kent, M.L. and Taylor, M. (2002), "Toward a dialogic theory of public relations", Public Relations Review, Vol. 28 No. 1, pp. 21-37, doi: 10.1016/S0363-8111(02)00108-X.

Kim, S., Kim, S.-Y. and Hoon Sung, K. (2014), "Fortune 100 companies ' Facebook strategies: corporate ability versus social responsibility", Journal of Communication Management, Vol. 18 No. 4, pp. 343-362, doi: 10.1108/JCOM-01-2012-0006.

Kiousis, S. (2002), "Interactivity: a concept explication", New Media and Society, Vol. 4 No. 3, pp. 355-383, doi: 10.1177/146144480200400303.

Lee, S. (2016), "How can companies succeed in forming CSR reputation?", Corporate Communications: An International Journal, Vol. 21 No. 4, pp. 435-449, doi: 10.1108/CCIJ-01-2016-0009.

Limongi França Coelho, R., Santos de Oliveira, D. and Severo de Almeida, M.I. (2016), "Does social media matter for post typology? Impact of post content on Facebook and Instagram metrics", Online Information Review, Vol. 40 No. 4, pp. 458-471, doi: 10.1108/OIR-06-2015-0176.

Luarn, P., Lin, Y.-F. and Chiu, Y.-P. (2015), "Influence of Facebook brand-page posts on online engagement”, Online Information Review, Vol. 39 No. 4, pp. 505-519.

Macnamara, J. (2014), "Emerging international standards for measurement and evaluation of public relations: a critical analysis", Public Relations Inquiry, Vol. 3 No. 1, pp. 7-29, doi: 10.1177/ $2046147 X 14521199$. 
Neill, M.S. and Moody, M. (2015), "Who is responsible for what? examining strategic roles in social media management”, Public Relations Review, Vol. 41 No. 1, pp. 109-118, doi: 10.1016/j.pubrev. 2014.10.014.

Pang, A., Shin, W., Lew, Z. and Walther, J.B. (2018), "Building relationships through dialogic communication: organizations, stakeholders, and computer-mediated communication", Journal of Marketing Communications, Vol. 24 No. 1, pp. 68-82, doi: 10.1080/13527266.2016.1269019.

Pierick, E.T., Beekman, V., Van der Weele, C.N., Meeusen, M.J. and De Graaff, R.P.M. (2004), "A framework for analysing corporate social performance; beyond the Wood Model (No. 10752016-87098)".

Pletikosa Cvijikj, I. and Michahelles, F. (2013), "Online engagement factors on Facebook brand pages", Social Network Analysis and Mining, Vol. 3 No. 4, pp. 843-861, doi: 10.1007/s13278-013-0098-8.

Quintly (2016), "Brand Study H1 2016: how do 30 of the biggest brands use Facebook?”, available at: https://www.quintly.com/blog/2016/10/30-biggest-brands-on-facebook-analyzed-in-depth/.

Rafaeli, S. (1988), "Interactivity: from new media to communication", Sage Annual Review of Communication Research: Advancing Communication Science, Vol. 16, pp. 111-134, available at: http://scholar.google.com/scholar?hl=en\&btnG=Search\&q=intitle:Interactivity: + From+New+Media+to+Communication\# $0 \% 5$ Cnfile:///Users/Home/Dropbox/Masters Thesis/Articles/Interactivity/Rafeili_?.Interactivity.pdf.

RivalIQ (2018), "2018 social media trends benchmark report", available at: https://get.rivaliq.com/hubfs/ eBooks/Rival_IQ_2018_Social_Media_Benchmark_Report.pdf?submissionGuid=5aa5c934-e84c4771-8f86-f1ee5e90b7e8.

Safko, L. and Brake, D.K. (2009), The Social Media Bible: Tactics, Tools, and Strategies for Business Success, Wiley, New Jersey.

Shin, W., Pang, A. and Kim, H.J. (2015), "Building relationships through integrated online media: global organizations' use of brand web sites, Facebook, and Twitter", Journal of Business and Technical Communication, Vol. 29 No. 2, pp. 184-220, doi: 10.1177/1050651914560569.

Sommerfeldt, E.J. and Yang, A. (2018), "Notes on a dialogue: twenty years of digital dialogic communication research in public relations", Journal of Public Relations Research, Vol. 30 No. 3, pp. 59-64, doi: 10.1080/1062726X.2018.1498248.

Sommerfeldt, E.J., Kent, M.L. and Taylor, M. (2012), "Activist practitioner perspectives of website public relations: why aren't activist websites fulfilling the dialogic promise?”, Strategically Managing International Communication in the 21st Century, Vol. 38 No. 2, pp. 303-312, doi: 10. 1016/j.pubrev.2012.01.001.

Statista (2017), "Average number of weekly posts on social media in the U.S. 2015", available at: https://www.statista.com/statistics/620974/average-number-brand-posts-social-media/ (accessed 15 May 2017).

Sundstrom, B. and Levenshus, A.B. (2017), "The art of engagement: dialogic strategies on Twitter", Journal of Communication Management, Vol. 21 No. 1, pp. 17-33, doi: 10.1108/JCOM-072015-0057.

Taylor, M. and Kent, M.L. (2014), "Dialogic engagement: clarifying foundational concepts", Journal of Public Relations Research, Vol. 26 No. 5, pp. 384-398, doi: 10.1080/1062726X.2014.956106.

Walther, J.B., Deandrea, D., Kim, J. and Anthony, J.C. (2010), "The influence of online comments on perceptions of Antimarijuana Public Service announcements on YouTube", Human Communication Research, Vol. 36 No. 4, pp. 469-492, doi: 10.1111/j.1468-2958.2010.01384.x.

Waters, R.D., Burnett, E., Lamm, A. and Lucas, J. (2009), "Engaging stakeholders through social networking: how nonprofit organizations are using Facebook", Public Relations Review, Vol. 35 No. 2, pp. 102-106, doi: 10.1016/j.pubrev.2009.01.006.

Wissen, N.V. (2017), "Building stakeholder relations online: how nonprofit organizations use dialogic and relational maintenance strategies on Facebook", Communication Management Review, Vol. 2, April, pp. 54-74, doi: 10.22522/cmr20170119.

\section{Assessing dialogic features on Facebook}


Wood, D.J. (1991), “Corporate social performance revisited”, Academy of Management Review, Vol. 16 No. 4, pp. 691-718.

Wright, D.K. and Drifka Hinson, M. (2017), "Tracking how social and other digital media are being used in public relations practice: a twelve-year study", Public Relations Journal, Vol. 11 No. 1, pp. 1-30, available at: https://prjournal.instituteforpr.org/wp-content/uploads/PRJ-2017-WrightHinson-2-1.pdf.

Zeler, I. and Capriotti, P. (2017), "Facebook como herramienta de Relaciones Públicas en las empresas: información de negocios y de RSE en las empresas con mejor reputación a nivel mundial", Revista Internacional de Relaciones Públicas, Vol. VII No. 14, pp. 145-164, doi: 10.5783/RIRP-142017-09-145-164.

Zeler, I. and Capriotti, P. (2018), "Gestión interactiva de la comunicación de la RSE de las empresas de Argentina en Facebook”, Retos, Vol. 8 No. 16, pp. 7-18, doi: 10.17163/ret.n16.2018.01.

\section{About the authors}

Paul Capriotti holds a $\mathrm{PhD}$ in communication from the Autonomous University of Barcelona (Spain). He is professor of public relations and corporate communication at the Rovira i Virgili University (URV) in Tarragona (Spain). He is CEO of Bidireccional, a consultancy firm specializing in measurement and evaluation of reputation and communication strategy (Mainmedia). He is author of different books and articles in Spanish and international journals and guest professor at different Spanish and Latin American universities.

Ileana Zeler, $\mathrm{PhD}$, is a Serra Hunter Fellow in the Department of Advertising, Public Relations and Audiovisual Communication at the Autonomous University of Barcelona (UAB). She is author of several articles in international scientific journals. Her research is focused on organizational communication, public relations, corporate social responsibility and social media. She is also Organizational and Strategic Communication Representative of the YECREA. Ileana Zeler is the corresponding author and can be contacted at: ileana.zeler@uab.cat

Andrea Oliveira, PhD, is a Serra Hunter Fellow at the Department of Philology and Communication, University of Girona (UdG), Girona, Spain. She has participated in several research projects, and the Spanish Agency for Quality Assessment and Accreditation (ANECA) accredited her as senior professor in social and juridical sciences in recognition of her academic career. With several articles published in prestigious international journals, her research focuses on "strategic communication," "communication and health," "public relations," "crisis management," "issue management" and "social media." She teaches in the degree in communications (UdG) and in master's degree in marketing and strategic communications (UOC and EAE Business School).

For instructions on how to order reprints of this article, please visit our website:

www.emeraldgrouppublishing.com/licensing/reprints.htm

Or contact us for further details: permissions@emeraldinsight.com 